\title{
Cytotoxicity Test of 4-Methacryloxyethyl Trimellitic Anhydride-based Dentine Bonding Material Using Acetone Solution in Dental Pulp Fibroblast
}

\author{
Adioro Soetojo ${ }^{1}$, Dewi Purnama², Cecilia G. J. Lunardhi', Ira Widjiastuti ${ }^{1}$ \\ 'Department of Conservative Dentistry, ${ }^{2}$ Resident in Department of Conservative Dentistry, Faculty of Dental Medicine, Universitas Airlangga, Surabaya, Indonesia
}

\section{Abstract}

Aims and Objectives: Both carious and non-carious lesions covering large dentine areas are indisputable indications of the need to use dentine bonding. Clinically, dental preparation, which is subsequently subjected to dentine bonding application often results in post-restorative pain. Various studies suggest that post-restorative pain is caused by the presence of residual monomers from the imperfect polymerization of a bonding material. The residual monomer can be a free radical that will induce oxidative stress conditions producing a toxic effect on 4-methacryloxyethyl trimellitic anhydride (4-META) monomer as the base material of dentine bonding. The aim of the study was to determine the toxic concentration of 4-META dentine bonding material using acetone as a solvent that destroys 50\% of the dental pulp fibroblast cells. Materials and Methods: Human pulp fibroblast cells contained in each well were treated with 4-META-acetone solution at concentrations of 5000, 2500, 1250, 625, 312.5, 156.25, 78.12, 39.06, 19.53, and 9.76 $\mu \mathrm{g} / \mathrm{mL}$. Two wells were left untreated to form the control group. A cytotoxicity test was performed by means of an 3-(4,5-Dimethylthiazol-2-yl)-2,5diphenyltetrazolium bromide (MTT)-assay test. The optical density of each well was measured with an enzyme-linked immunosorbent assay (ELISA) reader and the percentage of human pulp fibroblast cell destroyed was calculated using the appropriate formula. Results: The concentration of 4-META-based dentine bonding with acetone solvent capable of causing 50\% human pulp fibroblast cell death $\left(\mathrm{LC}_{50}\right.$ ) was $1250 \mu \mathrm{g} / \mathrm{mL}$. Conclusion: Toxic concentrations are those greater than or equal to $1250 \mu \mathrm{g} / \mathrm{mL}$.

Keywords: Acetone, Cytotoxicity, Dentine Bonding, Fibroblast Cells, 4-Methacryloxyethyl Trimellitic Anhydride

\section{INTRODUCTION}

Composite resin has positive aesthetic characteristics due to its wide variety of colors and combination of translucence and opacity. ${ }^{[1]}$ However, composite resin restoration of a large lesion involving dentine requires the application of adhesive substances in sufficient enamel that remains. The adhesive materials, referred to as dentin bonding, can adhere to wet dentin surfaces, thus improving the retention of composite resin in composite restoration. ${ }^{[2]}$ The location of carious lesions requiring dentine bonding as an adhesive substance is the deep proximal section, and the surrounding area of a filling requires a strong bond between the dentine and restorative material. Thus, dentine bonding is an absolute necessity in both carious and non-carious lesions involving extensive dentine surfaces. ${ }^{[3]}$ Basically, the working principles of

\begin{tabular}{|l|l|}
\hline \multicolumn{2}{|c|}{ Access this article online } \\
\hline Quick Response Code: & Website: \\
& www.jioh.org \\
\cline { 2 - 2 } & \\
\hline
\end{tabular}

a dentine bonding system are the physical-mechanical bond and the chemical interaction between the dentine bonding material and the collagen tissue located on the subsurface of the dentinal surface. ${ }^{[4]}$ The main purposes of this adhesive system are to create a stable bond between the restorative material and the tooth itself, as well as to cover the dentine surface. ${ }^{[5]}$

Clinically, tooth preparation for a restorative resin composite using dentin bonding often results in

\section{Address for correspondence: Dr. Adioro Soetojo, Department of Conservative Dentistry, Faculty of Dental Medicine, Universitas Airlangga, Jalan Prof. Dr. Moestopo No. 47, Surabaya 60132, Indonesia. E-mail: adioro-s@fkg.unair.ac.id}

This is an open access journal, and articles are distributed under the terms of the Creative Commons Attribution-NonCommercial-ShareAlike 4.0 License, which allows others to remix, tweak, and build upon the work non-commercially, as long as appropriate credit is given and the new creations are licensed under the identical terms.

For reprints contact: reprints@medknow.com

How to cite this article: Soetojo A, Purnama D, Lunardhi CG, Widjiastuti I. Cytotoxicity test of 4-methacryloxyethyl trimellitic anhydride-based dentine bonding material using acetone solution in dental pulp fibroblast. J Int Oral Health 2019;11:191-6. 
post-restorative pain. ${ }^{[6]}$ Various studies suggest that this type of post-restorative pain is caused by the presence of residual monomers from the imperfect polymerization of the bonding material. The unpolymerized monomers may alter the biocompatibility of the material. ${ }^{[5]}$ Previous research confirmed that a large amount of residual monomer was found to be cytotoxic. ${ }^{[5,7]}$ On a certain occasion, the residual monomers can transform into free radicals, which induce an oxidative stress condition. ${ }^{[8]}$ Free radicals represent negative ions that do not bind to other ions in the atomic orbit, thereby attracting other free radicals around them.

There are various commonly used dentine bonding materials, for example, 2-HydroxyEthyl Methacrylate (HEMA), 4-methacryloxyethyl trimellitic anhydride (4-META), Methyl methacrylate (MMA), Triethylene Glycol Dimethacrylate(TEDGMA), among others. ${ }^{[9]}$ Trubiani et al. ${ }^{[10]}$ concluded that many of the constituents are likely to cause cellular stress and have a significant cytotoxic effect. Nevertheless, a study by Olivier et al. ${ }^{[7]}$ showed that several dentin bondings contain various monomers, dentin bonding containing 4-META being the least toxic. With its low cytotoxicity, ${ }^{[1]}$ hydrophobic and hydrophilic properties, and ability to penetrate the hard tissue of the tooth to form a hybrid layer in dentin, ${ }^{[12]}$ 4-META is a promising material for use as a single monomer in dentin bonding.

In addition to their monomer composition, dentin bonding materials also contain solvent, which plays an important role in diffusing the monomers between collagen fibrils. ${ }^{[13]}$ As a solvent, acetone is commonly used in dentin bonding material due to its ability in attracting the moisture to prevent the breakdown of collagen fibrils before evaporating and being replaced by 4-META, thus resulting in a good binding between monomer and collagen fibrils. ${ }^{[9,13]}$ A study by Prasetyo et al. ${ }^{[14]}$ confirmed that 4-META bonding agent featuring acetone solvent shows superior chemical bond strength compared to that containing ethanol solvent.

The cells most affected by dentine bonding are the fibroblast cells contained in the pulp. The level of toxicity can usually be seen through the difference in the number of cells, which undergo apoptosis and necrosis. The toxicity level of a chemical substance is proportionate to its concentration. Usually, the higher the concentration of a substance, the higher the level of toxicity produced. The toxic nature of a chemical substance is determined by $\mathrm{LC}_{50}$ (lethal concentration). ${ }^{[15]}$

Commercial dentine bondings containing 4-META are usually added with many other materials to optimize their effect, ${ }^{[7]}$ which added the cost and made the commercial dentine bonding expensive.
With the aim to improve and widen the treatment to the patient, an inexpensive alternative of dentine bonding agent is needed. Despite the potency of 4-META as a single monomer in dentin bonding agent with acetone as its solvent, which means a lower production cost, a study observing the cytotoxicity of this combination is yet to be conducted. One of the requirements that should be fulfilled by adhesive systems as biomaterials is the biocompatibility and cytotoxicity assessment, which denotes a prerequisite to evaluate the biocompatibility of a material. ${ }^{[16]}$ Thus, this study intended to determine the toxicity concentration of 4-META dissolved in acetone as a bonding agent, which causes $50 \%$ mortality of dental pulp fibroblast cells $\left(\mathrm{LC}_{50}\right)$.

\section{Materials and Methods}

This study featured posttest-only control group design. The procedure was approved by the Ethical Clearance Board of the Faculty of Dental Medicine, Universitas Airlangga, Surabaya, Indonesia (Certificate no. 122/ HRECC.FODM/VIII/2017).

The research samples consisted of dental pulp fibroblast cells cultured from first upper human premolars (P1) extracted for orthodontic treatment purposes. The tooth were collected from the patients after signing a consent form. The inclusion criteria for the tooth were the first upper human premolars (P1) extracted for orthodontic treatment purposes from patients with age range of 16-18 years, with healthy condition without caries or cracks, no tooth mobility, and no periodontal abnormalities. Tooth exclusion criteria were tooth with mobility, dilaceration root, and difficult to extract. These pulp fibroblast cell cultures were prepared 2 months before cell treatment at LPPT Gadjah Mada University, Yogyakarta, Indonesia. The first premolars (P1) of 16-year-olds were washed with phosphate-buffered saline (PBS) before being divided into two sections using a low speed, tungsten carbide round bur no. 014 (MANI, Tochigi, Japan). The pulps were removed, sliced into small pieces with scissors, and subsequently minced using a scalpel. The minced pulps were then placed on petri dishes containing complete media (Dulbecco's Modified Eagle Medium 10\%, Fetal Bovine Serum 10\%, trypsin $1 \%$, fungizone $0.5 \mu \mathrm{g} / \mathrm{mL}$, and Pen strep 1\%-2\%) (Gibco, Welltham, Massachusetts), covered by deck glasses and then placed in the $\mathrm{CO}_{2}$ incubator to be cultured. The media were changed once every 3-4 days until long, spindle-shaped fibroblast cells appeared [Figure 1].

The procedure of fibroblast cell culture was through some passages until the fibroblast cells were ready to treat. Passage 1: After $80 \%$ fibroblast cells grow (seen and calculated under a microscope), the pulp in the petri dish is removed so that it only leaves confluent fibroblast cells. After the cells are confluent, the cells are harvested and 
then stripped so that the cells are released from the petri dish wall and then centrifuged. Next the cell is inserted into the flask (the cell is not yet stable). Passage 2: The cells in the flask are replaced by complete media every $3-4$ days until $80 \%$ fibroblast cells grow (seen and calculated under a microscope). In this phase, cells are developed so that the number is more (subculture). Passage 3: Treatment is the same as passage 2. Cells in passage 3 are considered stable and ready to be treated.

After the three aforementioned passages, fibroblast cells were ready to harvest. There were approximately $80 \%-$ $90 \%$ confluent fibroblast cells (seen under a microscope). Later, dispose the medium in the flask and wash the flask using a medium without FBS. Insert the medium in the flask and then shake to remove the remnants of FBS that are still attached to the cell, and then pour. Add trypsin- ethylenediaminetetraacetic acid (EDTA) $0.25 \%$ 1-2 $\mathrm{mL}$ and stand for a while, until the cell is released (rounded). Insert into the centrifuge tube, add medium until full. Centrifuge for $10 \mathrm{~min}$ at $1500 \mathrm{rpm}$ [Figure 2]. Remove the supernatant and then add $1 \mathrm{~mL}$ of complete medium, homogenized. Last, calculate cells obtained (cells ready for treatment).

This study used 4-META gel (Chemlin UK, Nanjing, China), which contains residual solvent (ethyl acetate) and 5\% polymerization inhibitor butylhydroxytoluene as the base material of dentine bonding. Pure 4-META gel at a concentration of $95 \%$ was then titrated in $100 \%$ acetone solution (Cambridge Isotope Laboratories, Cambridge,

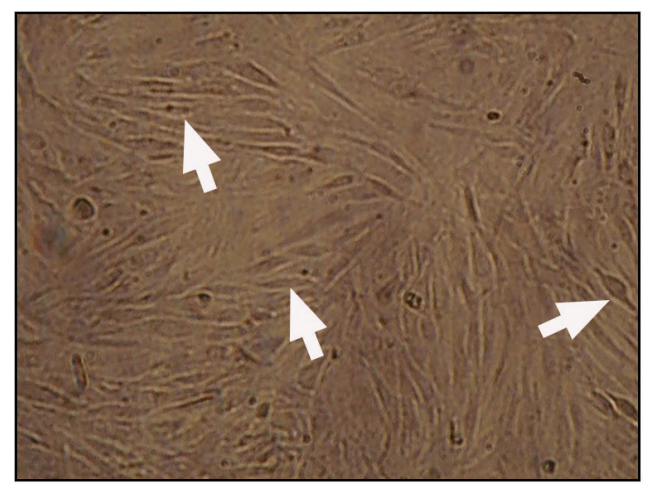

Figure 1: The white arrow shows microscopic images of living fibroblasts

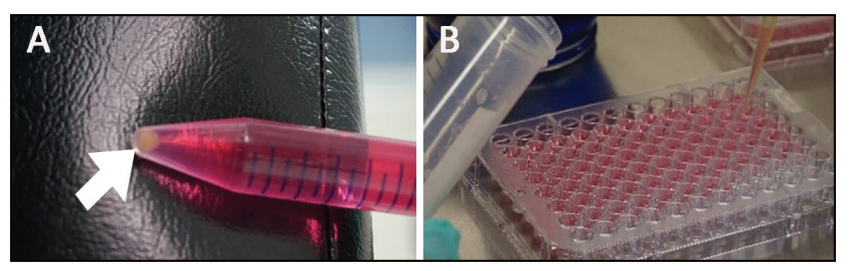

Figure 2: (A) Centrifugation results, white arrow shows the detached cells at the end of the tube. (B) Transfer cells to the 96-well plate as much as $100 \mu \mathrm{L}$ each
MA) at specific concentrations $(5000,2500,1250,625$, $312.5,156.25,78.12,39.06,19.53$, and $9.76 \mu \mathrm{g} / \mathrm{mL}){ }^{[17]}$

The cells were transferred to a 96-well microplate (IWAKI, Fukushima, Japan), each well containing $100 \mu \mathrm{L}$ pulp fibroblast cell suspension with a solidity of $2 \times 10^{4} / 20,000$ cells/well, before being left for $1-2 \mathrm{~h}$. Three wells were left empty to serve as the media control and three wells were filled with cells as the control. The cells were incubated inside a $\mathrm{CO}_{2}$ incubator for a minimum of $4 \mathrm{~h}$ to enable cell attachment after harvesting (cell sharing). A total of $100 \mu \mathrm{L}$ of a mixture of 4-META and acetone in specific concentrations were added after incubation to every well of each treatment group $(n=3)$ using a micropipette, before being incubated inside the $\mathrm{CO}_{2}$ incubator for $24 \mathrm{~h}\left(\mathrm{CO}_{2}\right.$ level, $5 \%$, temperature, $37^{\circ} \mathrm{C}$, humidity, $\left.98 \%\right)$. After $24 \mathrm{~h}$, the mixture was observed under Digital Carl Zeiss-Axioskop 40 microscope (Carl Zeiss Microscopy, Germany) and photographed by a SONY alpha 5000 camera (SONY, Tokyo, Japan). The wells containing the cells were washed with $100 \mu \mathrm{L}$ PBS, before $100 \mu \mathrm{L}$ MTT was added to each one (5 mg 3-(4,5-Dimethylthiazol-2-yl)2,5-diphenyltetrazolium bromide (MTT) $+1 \mathrm{~mL}$ PBS +9 $\mathrm{mL}$ complete medium/growing medium). The microplate was then incubated for $4 \mathrm{~h}$ until the formation of formazan occurred. Stopper solution of $100 \mu \mathrm{L}$ Sodium Lauryl Sulfate $10 \%$ was added to the $0.01 \mathrm{~N} \mathrm{HCl}$ in each well and the microplates were incubated overnight. A total of $50 \mu \mathrm{L}$ of dimethyl sulfoxide was added to each well, before being agitated for $5 \mathrm{~min}$ until the formazan crystals were completely diluted. Thereafter, they were counted using an enzyme-linked immunosorbent assay (ELISA) Reader Bio-RAD 680 XR (Bio-RAD Laboratories, Hercules, California) at a wavelength of $550 \mathrm{~nm}$. Blue color indicating the presence of formazan formation was found in the well containing living cells, whereas no color was found in the well devoid of living cells. The optical density recorded was then calculated using the Meyer formula::[18]

$$
\% \text { Cell death }=\frac{\text { Control OD }- \text { Sample OD }}{\text { Control OD }} \times 100 \%
$$

$$
\text { Explanation: } \mathrm{OD}=\text { Optical density }
$$

The data obtained was analyzed with the Statistical Package for the Social Sciences (SPSS) software, version 24 (IBM, Armonk, New York) using a Kruskal-Wallis test to identify the differences between all sample groups and a Tukey HSD test to establish the differences between each group. All samples were statistically analyzed with a confidence interval of $95 \%(P \leq 0.05)$.

\section{Results}

On the basis of toxicity test of 4-META-based dentine bonding material using acetone solution in dental pulp fibroblast cells, the percentages of fibroblast cell death calculated are present in Table 1. 
As the data were in homogen, the differences among groups were analyzed using Kruskal-Wallis test, which showed a significant difference among treatment groups $(P=0.001 ; 95 \% \mathrm{CI})$. The table shows that the concentration level resulting in $50 \%$ fibroblast cell death $\left(\mathrm{LC}_{50}\right)$ is one of $1250 \mu \mathrm{g} / \mathrm{mL}$. This means that the toxicity level of 4-META for the base material of dentine bonding in acetone solution is higher or equal to $1250 \mu \mathrm{g} / \mathrm{mL}$.

On the basis of Tukey HSD, significant differences were shown if only the mean value of each concentration belongs to different subset column. As shown in Table 1, 4-META-based dentine bonding material in acetone at $2500 \mu \mathrm{g} / \mathrm{mL}$ has no significant difference compared to $5000 \mu \mathrm{g} / \mathrm{mL}$ concentration. However, $1250 \mu \mathrm{g} / \mathrm{mL}$ concentration shows a significant difference compared to the other concentration. Thus, the significant difference means that the value of $\mathrm{LC}_{50}$ in 4-META-based dentine bonding material in acetone was at a concentration of $1250 \mu \mathrm{g} / \mathrm{mL}$. An image of microscopic living fibroblast cell, the necrotic fibroblast cell, and the lytic nucleus is shown in Figure 3.

\section{Discussion}

Dentine bonding is an agent used as a material to bond the restorative composite with dental tissues. It is often used together with composite resin to decrease the potential for microleakage in filling materials and dental surfaces while also promoting retention of the filling material. Generally, this material is a derivative of methacrylate resin, which is readily polymerized.$^{[5]}$

To penetrate the dental tissues, a dentine bonding should contain a component called solvent whose function is to help dilute the monomers and facilitate their penetration of demineralized dentine. ${ }^{[19]}$ All materials applied to living tissues have to be biocompatible meaning that the material can be absorbed by the body and does not cause any subsequent abnormalities or pathologic conditions. It also denotes that the material is neither toxic nor dangerous if applied to living tissues. ${ }^{[13]}$ Considering the close contact with dentine and vital pulp tissue, also in case of accidental contact with the other tissue in the oral cavity, a cytotoxicity test of the dentin adhesive material is necessary. However, cytotoxicity assessment of a material is mostly performed in cell culture due to ethical reasons. ${ }^{[16]}$

This research is based on several clinical phenomena related to postoperative pain after filling with composite resin and preceding the application of dentine bonding. ${ }^{[20]}$ Several research mention that the free monomers of dentine bonding materials are suspected of being one cause of postoperative pain and of teeth getting

\begin{tabular}{|c|c|c|c|c|}
\hline No. & Concentration of 4-META in acetone solution & Average of optical density & \% Cell death & $P$ value \\
\hline 1 & $5000 \mu \mathrm{g} / \mathrm{mL}$ & $0.091^{\mathrm{a}}$ & $88.70 \%$ & 0.001 \\
\hline 2 & $2500 \mathrm{\mu g} / \mathrm{mL}$ & $0.084^{a}$ & $89.60 \%$ & \\
\hline 3 & $1250 \mu \mathrm{g} / \mathrm{mL}$ & $0.402^{\mathrm{b}}$ & $50.30 \%$ & \\
\hline 4 & $625 \mu \mathrm{g} / \mathrm{mL}$ & $0.555^{\mathrm{c}}$ & $31.40 \%$ & \\
\hline 5 & $312,5 \mu \mathrm{gg} / \mathrm{mL}$ & $0.626^{\mathrm{d}, \mathrm{e}}$ & $22.60 \%$ & \\
\hline 6 & $156,25 \mu \mathrm{g} / \mathrm{mL}$ & $0.632^{\mathrm{d}, \mathrm{e}}$ & $21.80 \%$ & \\
\hline 7 & $78,12 \mu \mathrm{g} / \mathrm{mL}$ & $0.654^{e}$ & $19.16 \%$ & \\
\hline 8 & $39,06 \mu \mathrm{g} / \mathrm{mL}$ & $0.592^{\mathrm{c}, \mathrm{d}}$ & $26.80 \%$ & \\
\hline 9 & $19,53 \mu \mathrm{g} / \mathrm{mL}$ & $0.598^{\mathrm{c}, \mathrm{d}}$ & $27.10 \%$ & \\
\hline 10 & $9,76 \mu \mathrm{gg} / \mathrm{mL}$ & $0.670^{\mathrm{e}}$ & $17.20 \%$ & \\
\hline 11 & Control & $0.68^{\mathrm{f}}$ & $0 \%$ & \\
\hline
\end{tabular}
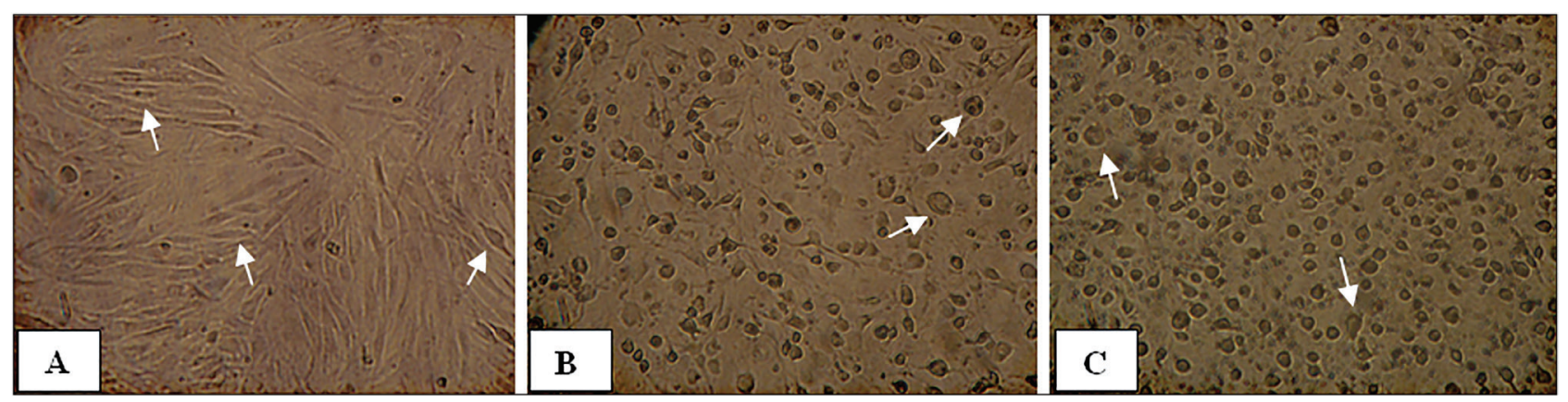

Figure 3: (A) Microscopic picture of living fibroblast cell (white arrows). (B) Microscopic picture of necrotic fibroblast cell, round, bulging with nucleus fragmentation (white arrows). (C) Lytic nucleus cannot be seen therefore the empty cavities bordered by nucleus membrane are called ghosts (white arrows) 
progressively necrotized. ${ }^{[21]}$ Pupo et al. ${ }^{[2]}$ analyzed the metabolic effects of several adhesive materials and revealed that the toxicity of the current adhesive systems varied, they suspected that it was likely related to the level of residual monomers. These free monomers have also been considered capable of damaging fibroblast cells in dentine and pulp tissue..$^{[5]}$

One of the most basic ingredients of the dentine bonding used is 4-META. Several studies have revealed that 4-META monomers can induce the death of surrounding tissues by producing free radicals from residual monomers because of imperfect polymerization. ${ }^{[21]}$

During the hydrolysis process, 4-META monomer contains a number of groups (-OH), which are forms of free radical reactive compounds called reactive oxygen species. ${ }^{[3]}$ In mitochondria, 4-META undergoes hydrolysis to become 4-MET whose chemical structure contains two hydroxyl groups (-OH). This allows 4-META to induce a toxic effect on the surrounding tissues causing cell death. In addition, high free monomer concentrations in registered cells can cause immunosuppression. ${ }^{[5]}$

There are several biochemical mechanisms thought to mediate cell death, which explain its occurrence because of the toxicity of a substance. Free radicals in cells cause oxidative stresses, which will result in the hyperactivation of poly (Adenosine Diphosphate (ADP)-ribose) polymerase-1 (PARP-1). ${ }^{[23]}$ PARP-1 hyperactivation will, in turn, inhibit glycolysis and ATP production. The inhibition of ATP production reduces the mount of Adenosine Triphosphate (ATP) and increases the free phosphate levels (the $\mathrm{pH}$ in cells increases). ATP constitutes a form of energy required by cells for various functional cell activities. Reduced ATP will disrupt cell activity, culminating in apoptosis. ${ }^{[24]}$ On the contrary, to manage reduced ATP production, cells carry out anaerobic glycolysis using residual glycogen and glucose reserves from surrounding tissue fluid. This leads to the accumulation of lactic acid and lower intracellular $\mathrm{pH} .{ }^{[25]}$

When the cell tries to neutralize the $\mathrm{pH}$, there is an interference with the transition of $\mathrm{Na}^{+}$and $\mathrm{Ca}^{2+}$ ions to the mitochondria. The ion exchange process requires ATP. ${ }^{[26]}$ When the amount of ATP decreases, interference to this process results, which ultimately causes the $\mathrm{Ca}^{2+}$ in the mitochondria to increase to excessive levels. ${ }^{[2]}$ Oxidative stress and $\mathrm{pH}$ recovery become normal combined with the overabundant presence of calcium in the cell and other factors such as high phosphate concentrations, causing the mitochondria to experience permeability transition. The opening of the mitochondrial permeability transition pore (MPTP) causes mitochondrial permeability transition (MPT), followed by the occurrence of mitochondrial internal membrane depolarization, matrix swelling, and rupture of the mitochondrial outer membrane. ${ }^{[25,28]}$
Morphological change constitutes a cell response to stress. Cell stress can be caused by substances that are toxic, mutagenic, and oxidative. ${ }^{[29]}$ Living fibroblasts are spindle-shaped, branching, and elongated with slim branches. ${ }^{[30]}$

According to Torabinejad et al.,${ }^{[31]}$ fibroblast cells are large, stellate-formed, resemble stars, and possess branches. If affected by lesions, they will experience morphological change characterized by the round-shaped cell, swollen because of nucleus fragmentation. The lytic nucleus cannot be seen, resulting in the empty cavities bordered by nucleus membrane being referred to as ghosts. This type of cell is a form of necrotizing fibroblast cell. ${ }^{[25]}$

In addition to the presence of residual monomers, that of acetone solvents also influences the presence of free radicals produced by 4-META monomers. Acetone is known to be a volatile solvent with weak hydrogen-binding capacity resulting in the poor performance of the antioxidant mechanism involved in free radical binding. ${ }^{[13]}$

According to Bakir et al. ${ }^{[5]}$ 4-META monomers induce adverse effects including cell death in tissues. The clinical procedure described earlier supports the aim of this study in determining the minimum toxic concentration of 4-META-based dentine bonding material in acetone solution, which can cause the death of $50 \%$ of dental pulp fibroblasts. By establishing the minimum toxic concentration of this dentine bonding material, dentists and researchers can understand more fully the safe concentrations, which should be used as dentin bonding. Moreover, this research is expected to give a description of the possibility in developing a new dentine bonding material with minimal toxicity.

The data show a significant difference among groups, which means that the concentration of 4-META in the dentine bonding in acetone solution contributes to the cell deaths. The bigger the concentration, the more toxic the bonding material. In the table containing the percentage of fibroblast cell deaths, it can be seen that not all decreases in the concentration of 4-META-based dentine bonding material using acetone solution result in a reduction in the percentage of fibroblast cell death. Certain lower concentrations were found to cause an increase in the percentage of fibroblast cell death. The Tukey HSD test results also confirmed insignificant levels of fibroblast cell death percentage decrease, even though the concentration decrease was significant. This was probably caused by acetone evaporation that increases 4-META concentration. ${ }^{[2]}$ The toxicity test was conducted on 4-META-based dentine bonding material in acetone solution to identify the toxic concentration, which causes $50 \%$ mortality among fibroblast cells. The results of this study show that a concentration of $1250 \mu \mathrm{g} /$ $\mathrm{mL}$ kills $50.30 \%$ of dental pulp fibroblast cells. Thus, the $\mathrm{LC}_{50}$ of this 4-META-based dentine bonding material is $1250 \mu \mathrm{g} / \mathrm{mL}$. 
The limitation of this study was the evaporation of acetone solvent was hard to control, resulting in a really short duration of application, which will give a difficulty in handling the bonding material. Thus, in the future, further improvement in its physical characteristic is needed.

Study results concluded that the concentration of 4-META-based dentine bonding material in acetone solution higher or equal to $1250 \mu \mathrm{g} / \mathrm{mL}$ is toxic, whereas a concentration lower than $1250 \mu \mathrm{g} / \mathrm{mL}$ is safe for dental pulp fibroblast cells.

\section{Financial support and sponsorship}

Nil.

\section{Conflicts of interest}

There are no conflicts of interest.

\section{RefEREnCes}

1. Nahsan FP, Mondelli RF, Franco EB, Naufel FS, Ueda JK, Schmitt VL, et al. Clinical strategies for esthetic excellence in anterior tooth restorations: Understanding color and composite resin selection. J Appl Oral Sci 2012;20:151-6.

2. Moreira Fdo C, Antoniosi Filho NR, Souza JB, Lopes LG. Sorption, solubility and residual monomers of a dental adhesive cured by different light-curing units. Braz Dent J 2010;21:432-8.

3. Nakajima M, Kunawarote S, Prasansuttiporn T, Tagami J. Bonding to caries-affected dentin. Jpn Dent Sci Rev 2011;47:102-14.

4. Soetojo A. Penggunaan Resin Komposit Dalam Bidang Konservasi Gigi. 1st ed. Surabaya, Indonesia: Revka Petra Media; 2013.

5. Bakir Ş, Bakir PB, Yildirim ZS. Biocompatibility of dental adhesives. Adv Dent Oral Heal 2017;4:1-6.

6. Berkowitz GS, Spielman H, Matthews AG, Vena D, Craig RG, Curro FA, et al. Postoperative hypersensitivity and its relationship to preparation variables in Class I resin-based composite restorations: Findings from the Practitioners Engaged in Applied Research and Learning (PEARL) Network. Part 1. Compend Contin Educ Dent 2013;34:e44.

7. Olivier A, Grobler SR, Osman Y. Cytotoxicity of seven recent dentine bonding agents on mouse 3T3 fibroblast cells. Open J Stomatol 2012;2:244-50.

8. Schweikl H, Spagnuolo G, Schmalz G. Genetic and cellular toxicology of dental resin monomers. J Dent Res 2006;85:870-7.

9. Van Landuyt KL, Snauwaert J, De Munck J, Peumans M, Yoshida Y, Poitevin A, et al. Systematic review of the chemical composition of contemporary dental adhesives. Biomaterials 2007;28:3757-85.

10. Trubiani O, Caputi S, Di Iorio D, D’Amario M, Paludi M, Giancola R, et al. The cytotoxic effects of resin-based sealers on dental pulp stem cells. Int Endod J 2010;43:646-53.

11. Hikage S, Sato A, Suzuki S, Cox CF, Sakaguchi K. Cytotoxicity of dental resin monomers in the presence of S9 mix enzymes. Dent Mater J 1999; 18:76-86.

12. Chang JC, Hurst TL, Hart DA, Estey AW. 4-META use in dentistry: A literature review. J Prosthet Dent 2002;87:216-24.
13. Ekambaram M, Yiu CKY, Matinlinna JP. An overview of solvents in resin-dentin bonding. Int J Adhes Adhes 2015;57:22-33.

14. Prasetyo AI, Kunarti S, Soetojo A, Prasetyo EA. Chemical bond strength difference between 4-META bonding agents with ethanol and acetone solvent on Type I collagen. J Int Dent Med Res 2018;11: $567-71$.

15. Zhang M, Aguilera D, Das C, Vasquez H, Zage P, Gopalakrishnan V, et al. Measuring cytotoxicity: A new perspective on LC50. Anticancer Res 2007:27:35-8.

16. Catunda R-Q, Jeymesson-Raphael-Cardoso Vieira E-B, de Oliveira E-C da S, Veruska-Lima-Moura Brasil D-E. Cytotoxicity evaluation of three dental adhesives on vero cells in vitro. J Clin Exp Dent 2017;9:e61-6.

17. Keler C, Balutis T, Bergen K, Laudenslager B, Rubino D. Serial dilution simulation lab. Am Biol Teach 2010;72:305-7.

18. Siregar F, Hadijono BS. Uji sitotoksisitas dengan esei MTT. J Dent Indones 2000;7:28-32.

19. Breschi L, Maravic T, Cunha SR, Comba A, Cadenaro M, Tjäderhane L, et al. Dentin bonding systems: From dentin collagen structure to bond preservation and clinical applications. Dent Mater 2018;34:78-96.

20. Survashe M, Parekh M. Immediate post-operative sensitivity after composite resin restoration-A review of treatment protocol. Int J Dent Oral Heal 2016:2:16-23.

21. Unemori M, Matsuya Y, Akashi A, Goto Y, Akamine A. Composite resin restoration and postoperative sensitivity: Clinical follow-up in an undergraduate program. J Dent 2001;29:7-13.

22. Pupo YM, Bernardo CFF, de Souza FFFA, Michél MD, Ribeiro CNM, Germano S, et al. Cytotoxicity of etch-and-rinse, self-etch, and universal dental adhesive systems in fibroblast cell line 3T3. Scanning 2017;2017:9650420.

23. Liu C, Fang Y. New insights of poly (ADP-ribosylation) in neurodegenerative diseases: A focus on protein phase separation and pathologic aggregation. Biochem Pharmacol 2019;pii:S0006-2952(19)30163-7.

24. Ye N, Zhang N, Zhang Y, Qian H, Wu B, Sun Y. Cul4a as a new interaction protein of PARP1 inhibits oxidative stress-induced H9c2 cell apoptosis. Oxid Med Cell Longev 2019;2019:1-10.

25. Vanlangenakker N, Vanden Berghe T, Krysko DV, Festjens N, Vandenabeele P. Molecular mechanisms and pathophysiology of necrotic cell death. Curr Mol Med 2008;8:207-20.

26. Bagur R, Hajnóczky G. Intracellular $\mathrm{Ca} 2+$ sensing: Its role in calcium homeostasis and signaling. Mol Cell 2017;66:780-8.

27. Szewczyk A, Bednarczyk P, Jędraszko J, Kampa RP, Koprowski P, Krajewska M, et al. Mitochondrial potassium channels: An overview. Postepy Biochem 2018;64:196-212.

28. Mnatsakanyan N, Park H-A, Wu J, Miranda P, Jonas EA. Molecular composition, structure and regulation of the mitochondrial permeability transition pore. Biophys J 2018;114:658a.

29. Fulda S, Gorman AM, Hori O, Samali A. Cellular stress responses: Cell survival and cell death. Int J Cell Biol 2010;2010 214074.

30. Wu M, Wang J, Zhang Y, Liu H, Dong F. Mineralization induction of gingival fibroblasts and construction of a sandwich tissue-engineered complex for repairing periodontal defects. Med Sci Monit Int Med J Exp Clin Res 2018;24:1112-23.

31. Torabinejad M, Fouad A, Walton RE. Endodontics: principles and practice. St. Louis: Elsevier Health Sciences; 2014 Jul 16. 